on the west coast of France; and it frequently visits the English Channel, pursuing the shoals of mackerel and pilchards. In the Museum of the College of Surgeons is the skeleton of a fine adult animal, which when alive must have been about seven feet long, taken near the beginning of the present century at Worthing. Northwards of this locality it appears to become rare. Van Beneden does not include it among the Cetacea frequenting the Belgian coast, as he was not able to find any example of its capture in the North Sea. Specimens, however, are occasionally met with on the coast of Norway and Denmark, as mentioned by Lilljeborg and Reinhardt ; and although it is included in many of the lists of the Cetacea of the Greenland Seas, it is doubtful whether some of the species of Lagenorhynchus may not have been mistaken for it.

Mr. Buckland has added a cast of this specimen to his valuable series of models of Cetacea, which exhibit better than any other method yet devised the form, proportions, and colour of these animals, otherwise so difficult of preservation.

\title{
May $6,1879$.
}

Prof. Flower, F.R.S., President, in the Chair.

The Secretary read the following report on the additions to the Society's Menagerie during the month of April 1879:-

The total number of registered additions to the Society's Menagerie during the month of April 1879 was 110, of which 3 were by birth, 77 by presentation, 3 by purchase, 8 by exchange, and 19 were received on deposit. The total number of departures during the same period by death and removals was 115 .

The most noticeable additions during the month of April were as follows :-

1. Two Lanceolated Jays (Garrulus lanceolatus, Vigors) from the Himalayas, received in exchange April lst. This fine bird, a close ally of our well-known Jay, has not, so far as I am aware, been brought to Europe alive previously.

2. Two female Roe-deer (said to have been brought from China, and purchased by one of the Society's correspondents at Marseilles), received in exchange April 3rd. These Deer are probably referable to the Capreolus pygargus (Pallas), and differ from the European species in having a longer body and head, and being higher on the legs. The colour is much darker, and appears to be red in the summer coat. The ears are longer and more pointed.

3. A fine young male of the Japanese Goat-Antelope (Capricornus crispus $^{1}$ ) presented by the Society's Corresponding Member, Mr. H. Pryer, of Yokohama, Japan, and received April 12 th.

We owe Mr. Pryer many thanks for the trouble he has taken in obtaining for us this fine and rare animal, the first of its species which has ever reached us.

4. An Alpine Accentor (Accentor alpinus) received in exchange April 30th, being, it is believed, the first example of this little bird obtained in eaptivity.

1 Antilope crispa, Siebold, Faun. Japon. Mamm. p. 55, tab. xrii. 


\section{Contents (continued).}

\section{March 18, 1879.}

Page

The Secretary. Remarks upon the Japanese Deer (Cervus sika) $\ldots \ldots \ldots \ldots \ldots \ldots \ldots . \ldots \ldots 4$

1. On a new Species of Barn-owl from the Island of Viti-Levu. By Dr. G. Hartuavb, F.M.Z.S. .................................................. 295

2. On Female Deer with Antlers. By Edward R. Alston, F.L.S., F.Z.S., \&c......... 296

3. Remarks on some Parrots living in the Society's Gardens. By P. L. ScLAter, M.A., Ph.D., F.R.S., Secretary to the Society. (Plate XXVIII.)................... 299

4. Notes on the Visceral Anatomy of the Tupaia of Burmah (Tupaia belangeri). By A. H. GARrod, M.A., F.R.S., Prosector to the Society ..................... 301

5. Notes on the Anatomy of Helictis subaurantiaca. By A. H. GARrod, M.A., F.R.S., Prosector to the Society. (Plate XXIX.) ........................... 305

April 1, 1879.

The Secretary. Report on the additions to the Society's Menagerie in March $1879 \ldots \ldots .308$

Mr. Carl Bock. Letter from, addressed to the Secretary, containing remarks upon Capricornis sumatrensis .............................................. 308

Mr. Sclater. Exhibition of the Eggs collected by the naturalists of the "Challenger" Expedition............................................... 309

Mr. J. W. Clark, F.Z.S. Exhibition of a drawing of a Species of Lagenorhynchus lately taken

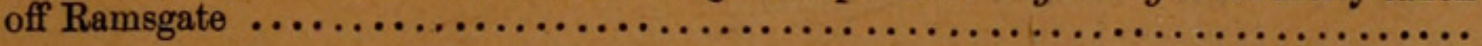

Mr. St. G. Mivart. Exhibition of a figure of a malformed Kestrel

1. A Contribution to the Avifauna of the Sooloo Islands. By R. BowdLer Sharpe, F.L.S., F.Z.S., \&c., Senior Assistant, Department of Zoology, British Museum.............

2. A List of the Birds of Labūan Island and its Dependencies. By R. BowdLer Sharpe, F.L.S., F.Z.S., \&c., Senior Assistant, Department of Zoology, British Museum.

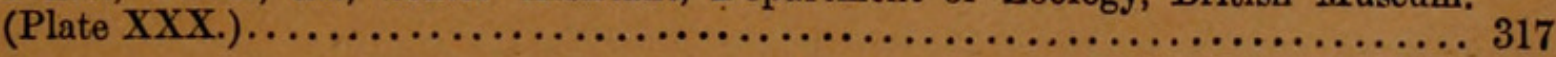

3. On the Conformation of the Thoracic Extremity of the Trachea in the Class Aves.Part I. The Gallinæ, By A. F. GARRoD, M.A., F.R.S., Prosector to the Society .. 354

4. On a new Fish of the Genus Lycodes from the Pacific. By Rosert Colletr, C.M.Z.S. 381

5. On the Common Dolphin, Delphinus delphis, Linn. By Wiluina Henry Flower, F.R.S., F.Z.S. ............................................. 382

May 6, 1879.

The Secretary. Report on additions to the Menagerie in April $1879 \ldots \ldots \ldots \ldots \ldots . .384$ 


\section{LIST OF PLATES.}

1879.

\section{PA R T II.}

Plate Page

XVII. Chiromachæris coronata $\ldots \ldots \ldots \ldots \ldots \ldots \ldots \ldots \ldots, 178$

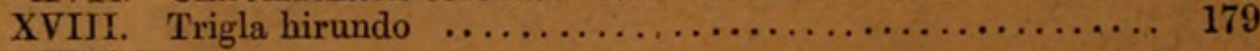

XIX. $\}$ Shells of Japan $\ldots \ldots \ldots \ldots \ldots \ldots \ldots \ldots \ldots \ldots \ldots \ldots, 181$

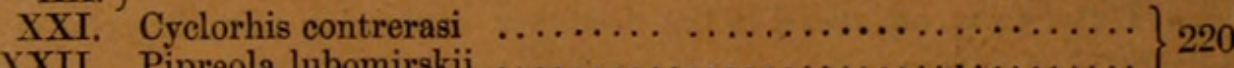

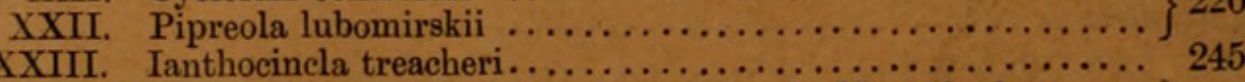

XXIV. Fig. 1. Myzomela chloroptera ; fig. 2. M. rubrobrunnea ;

fig. 3. M. adolphinæ ........................ ${ }_{256}$

XXV. Fig. 1. Myzomela chermesina ; fig. 2. M. sclateri .........

XXVI. [ Gasteracanthides $\ldots \ldots \ldots \ldots \ldots \ldots \ldots \ldots \ldots \ldots \ldots \ldots . \ldots \ldots$

XXVII.
XXVIII, Caica xanthomera $\ldots \ldots \ldots \ldots \ldots \ldots \ldots \ldots \ldots \ldots \ldots \ldots \ldots \ldots \ldots \ldots \ldots \ldots \ldots \ldots \ldots \ldots \ldots \ldots \ldots \ldots \ldots$

$\begin{array}{r}\text { XXVIII. } \\ \text { XXIX. Helictis subaurantiaca } \ldots \ldots \ldots \ldots \ldots \ldots \ldots \ldots \ldots \ldots \ldots \ldots \ldots \ldots \ldots \ldots \ldots \ldots \ldots \ldots \ldots \ldots \ldots \ldots \ldots \ldots \ldots \ldots \\ \hline\end{array}$

XXX. Fig. 1. Prionochilus everetti ; fig. 2. P. obsoletus.......... 317

\section{NOTICE.}

According to present arrangements the 'Proceedings' are issued in four parts,' as follows:-

Part I. containing papers read in January and February, on June lst.

II. " $\quad$ ". March and April, on August 1st.

III. " " " " " May and June, on October lst.

IV. " " " " $\quad$ "November and December, on April 1st.

The price is $12 s$. per part for the edition with coloured, and $3 s$. per part for that with uncoloured Plates. 


\section{$2 \mathrm{BHL}$ Biodiversity Heritage Library}

1879. "May 6, 1879. Prof. Flower, F.R.S., President, in the Chair." Proceedings of the Zoological Society of London 1879, 384-386. https://doi.org/10.1111/j.1096-3642.1879.tb02669.x.

View This Item Online: $\underline{\text { https://www.biodiversitylibrary.org/item/90455 }}$

DOI: https://doi.org/10.1111/j.1096-3642.1879.tb02669.x

Permalink: https://www.biodiversitylibrary.org/partpdf/73415

\section{Holding Institution}

Natural History Museum Library, London

\section{Sponsored by}

Natural History Museum Library, London

\section{Copyright \& Reuse}

Copyright Status: Public domain. The BHL considers that this work is no longer under copyright protection.

This document was created from content at the Biodiversity Heritage Library, the world's largest open access digital library for biodiversity literature and archives. Visit BHL at https://www.biodiversitylibrary.org. 